\title{
APLIKASI NUTRIEN BIOORGANIK CAIR DALAM PENGAWETAN HIJAUAN SEGAR
}

\author{
Kustiawan, $E^{1}$. dan Nurkholis ${ }^{2}$ \\ ${ }^{1}$ Email : erfan.kustiawan.polije@gmail.com \\ ${ }^{2}$ Email : nur78.nk@gmail.com
}

Jurusan Peternakan Politeknik Negeri Jember

\begin{abstract}
Abstrak
Kebutuhan biaya pakan mencapai 60-70\% dari total biaya produksi. Penyediaan hijauan dibatasi oleh musim, pada musim penghujan hijauan tersedia melimpah, sedangkan pada musim kemarau hijauan tidak cukup tersedia mengakibatkan harganya mahal, Musim kemarau para peternak sering dihadapkan pada masalah kekurangan bahan pakan hijauan. Di daerah tropika sering terjadi kemarau dimana pada musim ini terjadi kesukaran memperoleh hijauan sedangkan di musim hujan, hijauan makanan ternak berlimpah-limpah, keadaan tersebut mendorong timbulnya usaha untuk mengawetkan hijauan dalam bentuk segar. Pengawetan hijauan seperti halnya pada pembuatan silase, umumnya membutuhkan waktu yang relatif lama yaitu 21 hari, sehingga membuat peternak enggan untuk melakukan proses pengawetan hijauan tersebut. Penamabahan inokulan Bioorganik Cair lebih mempersingkat proses fermentasi yaitu 3-24 jam. Sehingga cara ini akan lebih efektif dan efisien untuk diaplikasikan di kelompok peternak Sido Makmur Semboro. Pengawetan pakan hijauan disamping meningkatkan nilai nutrien pakan, juga mengawetkan pakan dengan menggunakan teknologi fermentasi, yaitu menggunakan bakteri pembentuk asam laktat. Selama proses fermentasi asam laktat terus diproduksi sehingga pH akan rendah yang tidak memungkinkan aktifitas bakteri pembusuk berkembang, sehingga hijaun menjadi lebih awet.
\end{abstract}

Kata kunci : hijauan, biorganik cair, BAL

\section{PENDAHULUAN}

Musim kemarau para peternak sering dihadapkan pada masalah kekurangan bahan pakan hijauan. Di daerah tropika sering terjadi kemarau dimana pada musim ini terjadi kesukaran memperoleh hijauan sedangkan di musim hujan, hijauan makanan ternak berlimpah-limpah, keadaan tersebut mendorong timbulnya usaha untuk mengawetkan hijauan dalam bentuk segar.

Prinsip pengawetan pakan pada dasarnya adalah dengan memanfaatkan mikroorganisme dalam proses fermentasi. Fermentasi menghasilkan substrat primer dan metabolit sekunder dalam suatu lingkungan yang dikendalikan, dengan kata lain, fermentasi adalah perubahan struktur kimia dari bahan-bahan organik dengan memanfaatkan agen-agen biologis terutama enzim sebagai biokatalis. Di samping mampu mengawetkan hijauan pakan, teknologi pengawetan secara fermentasi dapat meningkatkan kualitas dari pakan itu sendiri. Berdasarkan hasil penelitian Syamsu (2006), komposisi nutrisi bahan pakan yang telah difermentasi dengan menggunakan starter mikroba sebanyak $0,06 \%$ dari berat bahan pakan, secara umum memperlihatkan peningkatan kualitas dibandingkan dengan bahan pakan sebelum/tidak difermentasi. Selanjutnya kadar protein kasar bahan pakan yang difermentasi mengalami peningkatan dan diikuti penurunan kadar serat kasar. Hal ini memberikan indikasi bahwa starter mikroba yang mengandung mikroba proteolitik yang menghasilkan enzim protease dapat merombak protein menjadi polipeptida yang selanjutnya menjadi peptide. 


\section{SOLUSI DAN TARGET}

\section{LUARAN}

Solusi dan target luaran dalam kegiatan

pengabdian ini dapat berupa;

a. Peningkatan pengetahuan, wawasan dan keterampilan petani peternak di Kelompok Tani Ternak Sido Makmur dalam pengawetan hijauan makanan ternak.

b. Terbentuknya Unit Pengolahan Hijauan Makanan Ternak di Kelompok Tani Ternak Sido Makmur.

c. Peningkatan kualitas hijauan pakan ternak di Kelompok Tani Ternak Sido Makmur.

\section{METODE PELAKSANAAN}

Kegiatan pemberdayaan Kelompok Tani Ternak Sido Makmur melalui kegiatan pengolahan hijauan segar menjadi silase yang dilakukan melalui metode penyuluhan dan pelatihan yang disertai aplikasi teknologi dalam bentuk percobaan "demplot" dengan jenis kegiatan:

1. Penambahan pengetahuan dan wawasan anggota kelompok terhadap pakan hijauan bagi ternak ruminansia

2. Peningkatan penguasaan teknologi pembuatan silase menggunakan Bioorganik Cair.

\section{HASIL DAN PEMBAHASAN}

Pihak mitra merupakan peternak sapi yang cukup produktif, hal ini dapat ditunjukkan dengan jumlah pemeliharaan sapi yang cukup banyak. Populasi sapi pihak mitra sebanyak 9 ekor induk, 4 ekor pedet betina dan 2 ekor pedet jantan. Populasi ini tentunya membutuhkan pakan hijauan yang cukup banyak dan harus merumput setiap hari, mulai pagi hingga siang hari. Kondisi ini yang dirasakan pihak mitra cukup berat untuk memperoleh hijauan, terutama pada musim kemarau. Salah satu upaya yang dilakukan oleh pelaksana pengabdian adalah dengan melakukan pengawetan hijauan segar, sehingga ternak tetap berproduksi dengan baik. Selain itu memberikan terobosan kepada pihak mitra untuk mengubah perilaku beternak yang tradisional (harus merumput setiap hari) menjadi beternak yang maju, salah satunya adalah penyediaan pakan hijauan dengan teknologi terapan yang sederhana dan mudah diaplikasikan, serta tidak perlu merumput setiap hari.

Aplikasi Bioorganik Cair sebagai bioaktivator memberikan hasil yang cukup memuaskan, karena dapat mempersingkat waktu proses fermentasi menjadi satu minggu dengan kualitas yang sama dengan proses fermentasi pakan berbasis limbah pertanian maupun hijauan segar pada umumnya. Dengan demikian penyediaan pakan berkualitas dan berkesinambungan pada usaha peternakan sapi potong dapat terwujud.

Keuntungan penerapan Bioorganik Cair sebagai pakan sapi adalah sebagai berikut:

1. Solusi permasalahan penyediaan hijauan sebagai pakan ternak pada musim kemarau.

2. Tersedianya pakan hijauan sepanjang musim dan mempermudah mitra dalam penyediaan hijauan berbasis limbah pertanian maupun hijauan segar yang diawetkan, sehingga mitra/peternak tanpa merumput setiap hari.

3. Meningkatkan nutrisi pakan hijauan dari limbah pertanian dan pakan hijauan awetan, serta meningkatkan daya cerna pakan. 
Tabel 1. Karakteristik Hijauan Segar Setelah Diawetkan Dengan Bioorganik Cair

\begin{tabular}{|c|c|c|c|c|}
\hline $\begin{array}{c}\text { Indikator } \\
\text { Pencapaian }\end{array}$ & Nilai & & Penjelasan & Nilai \\
\hline Aroma & 30 & 1. & $\begin{array}{ll}\text { Busuk } & \\
\text { Asam } & \\
\text { Seperti } & \text { aroma } \\
\text { buah, } & \text { sedikit } \\
\text { asam } & \end{array}$ & 25 \\
\hline Warna & 30 & 1. & $\begin{array}{l}\text { Hitam } \\
\text { Coklat agak hitam } \\
\text { Hijau kekuningan }\end{array}$ & 25 \\
\hline Tekstur & 40 & 1. & $\begin{array}{l}\text { Sangat basah } \\
\text { Sedikit basah } \\
\text { Sedikit basah dan } \\
\text { lunak } \\
\text { Kering dan lunak }\end{array}$ & 30 \\
\hline
\end{tabular}

Materi penyuluhan ini menitikberatkan pada pemahaman pihak mitra terhadap kandungan nutrisi pakan, terutama pada hijauan. Pakan hijauan yang telah dibuat/diawetakan menggunakan Bioorganik Cair selama empat hingga tujuh hari akan menghasilkan hijauan yang awet, aroma segar dan dapa meningkatkan kandungan nutrisinya. Artinya meningkatkan kandungan protein jerami dan menurunkan kandungan serat kasarnya. Materi penyuluhan diatas merupakan serangkaian pemahaman pihak mitra dalam melakukan pengawetan hijauan. Dengan menerapkan teknologi tepat guna ini diharapkan peternak sapi, khususnya pihak mitra tidak perlu repot mencari rumput setiap hari, bahkan bisa memproduksi dalam jumlah besar.

Hasil pengawetan hijauan yang dilakukan pihak mitra, awalnya memberikan hasil yang kurang memuaskan. Pakan hijauan awetan yang dibuat pihak mitra masih terdapat jamur. Proses pengawetan yang baik ditunjukkan dengan tidak tumbuhnya jamur dan memiliki bau asam yang segar. Kondisi ini kemungkinan disebabkan masih adanya oksigen atau tidak dalam kondisi anaerob. Hasil pembuatan selanjutnya yang dilakukan pihak mitra menghasilkan hijauan awetan yang baik, ditunjukkan dengan karakteristik hijauan nampak pada Tabel 1. 


\section{KESIMPULAN DAN SARAN}

\section{Kesimpulan}

Kegiatan pengabdian kepada masyarakat dalam bentuk kegiatan penyuluhan dan pelatihan pengawetan pakan hijauan menggunakan Bioorganik Cair dapat disimpulkan sebagai berikut :

1. Pengawetan pakan hijauan sapi potong dapat mengatasi permasalahan kekurangan pakan selama musim kemarau.

2. Penggunaan Bioorganik Cair efektif digunakan dalam proses pembuatan pakan hijauan awetan

3. Respon pihak mitra sangat tinggi untuk menerapkan Bioorganik Cair dalam pengawetan hijauan dan diikuti oleh peternak di sekitar pihak mitra.

\section{Saran}

Teknologi pengawetan pakan hijauan menggunakan Bioorganik Cair dalam penyediaan pakan hijauan yang tetap berkualitas diharapkan dapat diaplikasikan oleh peternak lainnya atau masyarakat di sekitar pihak mitra dengan cara memberikan/menularkan pengetahuannya secara luas.

\section{UCAPAN TERIMA KASIH}

Terima kasih yang sebesar-besarnya pada P3M POLIJE atas kepercayaan, dukungan dan pemberian pendanaan, sehingga dapat terlaksananya kegiatan pengabdian pada masyarakat di Kelompok Tani Ternak Sido Makmur

\section{DAFTAR PUSTAKA}

[1] Molyono S. 2011. Teknik Pembibitan Kambing dan Domba. Penebar Swadaya, Jakarta.

[2] Nista, D. 2007. Teknologi Pengolahan Pakan: UMB, Fermentasi Jerami, Amoniasi Jerami, Silase, dan Hay.

[3] Rukmana HR. 2005. Silase dan Permen Ternak Ruminansia. Kanisius, Yogyakarta.

[4] Susetyo S. 1980. Padang Penggembalaan. Modu1, Fakultas Peternakan Institut Pertanian Bogor.

[5] Syamsu, J.A., 2006. Kajian Penggunaan Starter Mikroba dalam Fermentasi Jerami Padi sebagai Sumber Pakan pada Peternakan Rakyat di sulawesi Tenggara. Prosiding Seminar Nasional Bioteknologi, Puslit Bioteknologi LIPI, Bogor. 